\title{
Dynamic Linkages between Green Energy, Knowledge Spillover, and Carbon Emissions: Global Evidence
}

\author{
Muhammad Khalid Anser ${ }^{1}$, Muhammad Azhar Khan², Abdelmohsen A. Nassani, \\ Muhammad Moinuddin Qazi Abro ${ }^{3}$, Khalid Zaman ${ }^{2 *}$, Ahmad Kabbani ${ }^{4}$ \\ ${ }^{1}$ School of Public Administration, Xi' an University of Architecture and Technology, Xi'an, China \\ ${ }^{2}$ Department of Economics, University of Haripur, Khyber Pakhtunkhwa, Haripur, Pakistan \\ ${ }^{3}$ Department of Management, College of Business Administration, King Saud University, \\ P.O. Box 71115, Riyadh, 11587, Saudi Arabia \\ ${ }^{4}$ Department of Management, Aleppo University, Aleppo, Syria
}

Received: 5 July 2020

Accepted: 31 October 2020

\begin{abstract}
Covering 3168 annual observations of 132 countries for 1995-2018, the study investigated the role of knowledge spillover (KNOW), renewable energy (RE) demand, and food production (FP) in mitigation of $\mathrm{CO}_{2}$ emissions to achieve global environmental sustainability (ES) agenda. The study used ArellanoBond (A-R) differenced GMM estimator to handle endogeneity and serial correlation issues for robust inferences. The results confirmed the hump-shaped relationship between $\mathrm{KNOW}$ and $\mathrm{CO}_{2}$ emissions to support 'Knowledge Kuznets curve (KKC)' across countries. The results further reveal that FDI inflows and trade openness (TOP) both increases $\mathrm{CO}_{2}$ emissions that substantiate the 'pollution haven hypothesis (PHH)'. The positive relationship between $\mathrm{FP}$ and $\mathrm{CO}_{2}$ emissions exhibits 'food footprints (FFP)' across countries. The negative relationship between $\mathrm{RE}$ demand and $\mathrm{CO}_{2}$ emissions imply that increased use of RE helps to reduce emissions, which is a positive sign to precede towards cleaner production technologies for achieving global ES agenda.
\end{abstract}

Keywords: carbon emissions, knowledge spillover, renewable energy demand, food production, GMM estimator

\section{Introduction}

The nexus between $\mathrm{CO}_{2}$ emissions and economic growth (EG) is largely discussed under the literature

*e-mail: khalid_zaman786@yahoo.com of environmental Kuznets curve (EKC) [1-2]. The study extended the EKC modeling by including $\mathrm{KS}$, RE demand, FP, FDI inflows, and TOP to testing the four different plausible hypotheses, including, $\mathrm{KKC}$, $\mathrm{PHH}$, FFP, and energy associated emissions (EAE). The $\mathrm{KKC}$ is the bond between $\mathrm{CO}_{2}$ emissions and $\mathrm{KS}$, which is expected to have a positive relationship at an initial level while it becomes negative at the 
later stages, thus it would exhibit a hump-shaped associated between the two variables [3-4]. The PHH shows the affirmative link between FDI (and TOP) and $\mathrm{CO}_{2}$ emissions, which validate the existence of dirty polluting industries that affect the country's EG [5]. The FFP correspond the affirmative association between $\mathrm{FP}$ and $\mathrm{CO}_{2}$ emissions that are an account of unsustainable use of production technologies, which led to an increase in health damages across countries [6-8], and finally, EAE is considered the affirmative connection between energy demand (ED) and $\mathrm{CO}_{2}$ emissions that could be reduced by the increasing use of RE demand across countries [9-11]. Thus, based on significant discussion, the study intended the following two research questions, i.e., i) does KS would be helpful to decrease $\mathrm{CO}_{2}$ emissions under economic resource policies, and ii) to what extent $\mathrm{RE}$ demand reduces $\mathrm{CO}_{2}$ emissions to support food challenges issues. Both the research questions are important to precede towards cleaner production agenda. The main objective of the study is to analyze the role of KS, FDI inflows, and TOP in mitigation of $\mathrm{CO}_{2}$ emissions. Further, the impact of $\mathrm{RE}$ demand and $\mathrm{FP}$ on $\mathrm{CO}_{2}$ emissions is evaluated, which linked it with the casual and anticipated liaison between the stated factors. The stated objectives would be achieved by using panel econometric techniques to get robust inferences.

\section{Material and Methods}

Table 1 shows the list of the variables. The variable $\mathrm{CO}_{2}$ emissions served as a 'response' variable while the remaining variables act as explanatory variables of the study. The data is taken from World Bank [12] database covering 3168 annual observations of 132 countries for 1995-2018. The study is inspired by the latest work of Shahbaz et al. [13], Nizam et al. [14], Anser et al. [15], Dogan et al. [16], Sarkodie \& Ozturk [17], etc. The study is unique as it added $\mathrm{KS}$ as a main explanatory variable that would provide more insights into $\mathrm{KKC}$ in the bond between emissions and income factors across countries. The study used the following equation for inferences, i.e.,

$$
\begin{gathered}
\ln \left(C O_{2}\right)_{i t}=\beta_{0}+\beta_{1} \ln \left(C O_{2}\right)_{i t-1}+\beta_{2} \ln (\text { KNOW })_{i t}+ \\
\beta_{3} \ln (S Q K N O W)_{i t}+\beta_{4} \ln (F D I)_{i t}+\beta_{5} \ln (T O P)_{i t}+ \\
\beta_{6} \ln (F P I N D E X)_{i t}+\beta_{7} \ln (R E C)_{i t}+\lambda_{i t}+\varepsilon_{i t}
\end{gathered}
$$

...where, $\chi$ shows list of instrumental variables, ' $i$ ' and ' $t$ ' shows 132 countries and time period is 1995-2018, and $\Sigma$ shows error term.

Equation (1) shows the different determinants of $\mathrm{CO}_{2}$ emissions in a panel of selected countries. It is expected that $\beta_{2}>0, \beta_{3}<0$ to verify the $\mathrm{KKC}$ hypothesis, whereas $\beta_{4}>0, \beta_{5}>0$ is expected to substantiate the PHH. The coefficient value of $\beta_{6}>0$ is expected to validate the FFP across countries. Finally, it is likely that the impact of REC on $\mathrm{CO}_{2}$ emissions will be negative $\left(\beta_{6}>0\right)$ that implies the need of more use of RE demand in cleaner production to lessen $\mathrm{CO}_{2}$ emissions accordingly. Equation (1) is empirically estimated by Arellano-Bond differenced GMM estimator that handled possible endogeneity and autocorrelation issue. Further instrumental reliability checked by Sargen -Hansen J-statistics and instrumental rank accordingly.

\section{Results and Discussion}

Table 1 show that $\mathrm{CO}_{2}$ emissions have a mean value of 0.645 metric tons per capita with a maximum value of 3.211 and standard deviation of 1.502. Additionally, KNOW has a mean value of 6.436 number counts of scientific \& technical journals with a maximum value of 12.995 counts. The mean value of FPINDEX, FDI inflows, TOP, and REC is about $4.634,0.942 \%$ of GDP, $4.279 \%$ of GDP, and $2.809 \%$ of energy consumption, respectively.

The GMM estimates show that FDI inflows and TOP both substantially increases $\mathrm{CO}_{2}$ emissions to substantiate $\mathrm{PHH}$. The stringent environmental regulations [18], carbon pricing [19], environmental governance [20], environmental certifications [21], resource management [22], and waste handling [23] are the few policy options to limit $\mathrm{CO}_{2}$ emissions, while financial and trade liberalization policies should be in tandem with green financing options and eco-friendly goods to sustained long-term sustainable development across countries [24]. The results further reveal that FPINDEX increases $\mathrm{CO}_{2}$ emissions with an elasticity estimate of $0.152 \%$ while increases $1 \%$ increase in FPINDEX, which confirmed the existence of FFP across countries. The need for progression in green production technologies [25], shifted non-renewable fuels with renewable fuels [26], food regulation and monitoring programmes [27], hygienic food production [28], low carbon oil-burning stoves [29], etc., are the few sustainable action policies to mitigate $\mathrm{CO}_{2}$ emissions. The hump-shaped relationship found between KNOW and $\mathrm{CO}_{2}$ emissions, as KNOW first increases $\mathrm{CO}_{2}$ emissions while its second-degree coefficient substantially decreases $\mathrm{CO}_{2}$ emissions to verify $\mathrm{KKC}$ hypothesis. The environmental KNOW is imperative for achieving countries towards long-term sustainable development. The campaigns for cleaning environment [30], waste disposal and recycling initiatives [31], eco-friendly production [32], sustainable consumption and production [33], extend environmental awareness at the grass root level [34], respond to the international call for ES [35], and all other modes of techniques through which environmental degradation should be reduced and compliance as per the international standard for environmental resource conservation are the vital factors to achieve a clean and green agenda. 
Table 1. Estimation Matrix.

\begin{tabular}{|c|c|c|c|c|c|}
\hline \multicolumn{6}{|c|}{ Descriptive Statistics } \\
\hline Variables & Average & Highest value & $\begin{array}{l}\text { Dispersion from } \\
\text { mean value }\end{array}$ & Skewness & Kurtosis \\
\hline $\begin{array}{l}\mathrm{CO}_{2} \text { emissions (metric tons } \\
\text { per capita) }\end{array}$ & 0.645 & 3.211 & 1.502 & -0.658 & 2.599 \\
\hline $\begin{array}{l}\text { KNOW (Scientific and } \\
\text { technical journal articles) }\end{array}$ & 6.436 & 12.995 & 2.852 & 0.010 & 2.256 \\
\hline $\begin{array}{l}\text { FPINDEX (Food production } \\
\text { index) }(2004-2006=100)\end{array}$ & 4.634 & 5.596 & 0.214 & 0.101 & 3.845 \\
\hline FDI Inflows ( $\%$ of GDP) & 0.942 & 6.113 & 1.238 & -0.859 & 6.565 \\
\hline TOP $(\%$ of GDP) & 4.279 & 6.080 & 0.661 & -3.475 & 35.435 \\
\hline $\begin{array}{l}\text { REC ( } \% \text { of total final energy } \\
\text { consumption) }\end{array}$ & 2.809 & 4.588 & 1.545 & -1.527 & 6.709 \\
\hline \multicolumn{6}{|c|}{ A-R Estimates: Dependent variable: $\ln \left(\mathrm{CO}_{2}\right)$} \\
\hline Variables & Coefficient & Standard Error & t-statistics & Prob.value & \multirow{2}{*}{ Statistical Tests } \\
\hline $\ln \left(\mathrm{CO}_{2}\right)_{\mathrm{t}-1}$ & 0.563 & 0.003 & 171.268 & 0.000 & \\
\hline $\ln (\mathrm{FDI})_{\mathrm{t}}$ & 0.005 & 0.0005 & 8.859 & 0.000 & J-statistic: 128.433 \\
\hline $\ln (\text { FPINDEX })_{t}$ & 0.152 & 0.005 & 27.420 & 0.000 & Prob.J-statistic: 0.422 \\
\hline $\ln (\mathrm{REC})_{\mathrm{t}}$ & -0.166 & 0.002 & -66.782 & 0.000 & Instrumental rank: 133 \\
\hline $\ln (\mathrm{KNOW})^{\mathrm{t}}$ & 0.117 & 0.005 & 23.089 & 0.000 & $\begin{array}{c}\text { Arellano-Bond Serial } \\
\text { Correlation Test }\end{array}$ \\
\hline $\ln (\mathrm{SQKNOW})_{\mathrm{t}}$ & -0.005 & 0.0004 & -12.277 & 0.000 & AR(1)-rho: -14.220 \\
\hline $\ln (\mathrm{TOP})_{\mathrm{t}}$ & 0.059 & 0.002 & 22.511 & 0.000 & AR(2)-rho: -0.674 \\
\hline \multicolumn{6}{|c|}{ VAR Granger Causality } \\
\hline $\mathrm{TOP} \leftrightarrow \mathrm{CO}_{2}$ & $\mathrm{CO}_{2} \rightarrow \mathrm{FDI}$ & KNOW $\leftrightarrow$ FDI & $\mathrm{TOP} \leftrightarrow \mathrm{FDI}$ & $\mathrm{CO}_{2} \rightarrow \mathrm{FPINDEX}$ & $\mathrm{FDI} \rightarrow \mathrm{FPINDEX}$ \\
\hline KNOW $\leftrightarrow$ FPINDEX & $\mathrm{CO}_{2} \rightarrow \mathrm{REC}$ & $\mathrm{KNOW} \leftrightarrow \mathrm{REC}$ & $\mathrm{TOP} \leftrightarrow \mathrm{REC}$ & $\mathrm{CO}_{2} \rightarrow \mathrm{KNOW}$ & TOP $\leftrightarrow$ KNOW \\
\hline \multicolumn{6}{|c|}{ IRF Estimates } \\
\hline $2019-2028$ & $\mathrm{FDI} \uparrow \mathrm{CO}_{2} \uparrow$ & FPINDEX $\uparrow \mathrm{CO} 2 \uparrow$ & $\mathrm{REC} \uparrow \mathrm{CO}_{2} \downarrow$ & $\mathrm{KNOW} \uparrow \mathrm{CO}_{2} \downarrow$ & $\mathrm{TOP} \uparrow \mathrm{CO} 2 \uparrow$ \\
\hline \multicolumn{6}{|c|}{ VDA Estimates } \\
\hline $2019-2028$ & $\begin{array}{l}\text { FDI influ- } \\
\text { enced } 44.9 \% \\
\text { to carbon } \\
\text { emissions }\end{array}$ & $\begin{array}{l}\text { REC influenced } \\
25 \% \text { to carbon } \\
\text { emissions }\end{array}$ & $\begin{array}{l}\text { TOP influenced } \\
15.4 \% \text { to carbon } \\
\text { emissions }\end{array}$ & $\begin{array}{l}\text { FPINDEX } \\
\text { influenced } 4 \% \text { to } \\
\text { carbon emissions }\end{array}$ & $\begin{array}{l}\text { KNOW influenced } 0.9 \% \\
\text { to carbon emissions }\end{array}$ \\
\hline
\end{tabular}

The Granger causality estimates confirmed the feedback relationship between i) TOP and $\mathrm{CO}_{2}$ emissions (and FDI, REC and KNOW), and ii) KNOW and FDI (and FPINDEX, REC, and TOP) while a causality is running from i) $\mathrm{CO}_{2}$ to FDI, FPINDEX, REC, and KNOW), and ii) FDI to FPINDEX across countries. The causality analysis is confirmed the mutual integration of TOP and $\mathrm{CO}_{2}$ emissions that moving in the same direction under the direction of FDI, REC, and KNOW, while KNOW moves together with the FDI inflows in the same direction with the conciliation of FPINDEX, REC, and TOP. The IRF estimates show that FDI inflows, FPINDEX, and TOP will increase $\mathrm{CO}_{2}$ emissions while it will subsequently decline with REC and KNOW across countries. The VDA estimates show that FDI inflows will be the largest contributor to influence $\mathrm{CO}_{2}$ emissions, followed by REC, TOP, and FPINDEX, while the least contributor will be KNOW to influence $\mathrm{CO}_{2}$ emissions over a time horizon.

\section{Conclusions}

The world economy affected by an enormous increase in $\mathrm{CO}_{2}$ emissions because of the high usage of fossil fuel combustion, industrialization, non-renewable energy use and technology embodied emissions. The current study took initiative to explore the dynamic relationship between KNOW, REC, FPINDEX and $\mathrm{CO}_{2}$ emissions in a panel of 132 countries by using a 
time series data from 1995 to 2018. The results show that KNOW first increases and later decreases carbon emissions to support KKC hypothesis. Further, FDI inflows, TOP, and FPINDEX positively associated with the high $\mathrm{CO}_{2}$ emissions that substantiate the $\mathrm{PHH}$ and FFP across countries. The study found the positive impact of REC on $\mathrm{CO}_{2}$ mitigation that corresponds to the need to substitute non-renewable fuel to renewable fuel to achieve ES agenda across countries. The Granger causality results show the unidirectional causality running from i) $\mathrm{CO}_{2}$ emissions to FDI inflows, FPINDEX, REC, and KNOW, and ii) FDI inflows to FPINDEX, while the bidirectional causality found between i) TOP and $\mathrm{CO}_{2}$ emissions, ii) KNOW and FDI inflows, iii) TOP and FDI inflows, iv) KNOW and FPINDEX, v) KNOW and REC, vi) TOP and REC and vii) TOP and KNOW. The estimates of an IRF show that FDI inflows, FPINDEX and TOP will increase $\mathrm{CO}_{2}$ emissions while KNOW and REC will decrease $\mathrm{CO}_{2}$ emissions. The VDA analysis shows that FDI inflows will be the largest contributor to influence $\mathrm{CO}_{2}$ emissions, followed by REC, TOP, FPINDEX, and TOP over a time horizon.

The study suggested the following policy formulation to achieve global ES agenda, i.e.,

- Short-term Policy Implication: The imposition of carbon taxes on dirty production is desirable to limit carbon emissions, followed by using ISOcertification, emissions trading pricing, hazardous material management, etc. Further, trade and financial liberalization policies should be sustainable to produce eco-friendly production through environmental certification programmes.

- Medium-term Policy Implication: Sustainable production and consumption is highly desirable to mitigate carbon emissions that can be achieved through the use of cleaner production technologies, technology spillover, knowledge diffusion, and waste management. The knowledge and technology spillover can be integrated by the cooperation of the developed countries, thus the mutual collaboration and cooperation of sustainable technology transfer from developed to developing countries could get mutual an exclusive global gain for environmental conservation.

- Long-term Policy Implication: The energy associated emissions are the major concern of the global economy and it's emphasized the need to limit the use of fossil fuel combustion and other non-renewable energy sources to achieve a sustainability agenda. Using renewable energy sources in existing energy portfolio would be helpful to reduce global average temperature, as mentioned in the mission statement of COP-21 agenda to reduce global temperature less than $1.5^{\circ} \mathrm{C}$. The global economy should strive hard to combat climate change and mitigate GHG emissions through substituting fossil fuel to renewable energy sources, technology embodied emissions to cleaner production technologies, and dirty production to eco-friendly production through stringent environmental regulations and knowledge spillovers. All these sources would desire to move forward for clean and green development across the globe.

\section{Acknowledgements}

Researchers Supporting Project number (RSP2021/87), King Saud University, Riyadh, Saudi Arabia.

\section{Conflict of Interest}

The authors declare no conflict of interest.

\section{References}

1. STERN D.I. The rise and fall of the environmental Kuznets curve. World development, 32 (8), 1419, 2004.

2. DINDA S. Environmental Kuznets curve hypothesis: a survey. Ecological economics, 49 (4), 431, 2004.

3. ZHANG Y.J., PENG Y.L., MA C.Q., SHEN B. Can environmental innovation facilitate carbon emissions reduction? Evidence from China. Energy Policy, 100, 18, 2017.

4. HEGGEDAL T R., JACOBSEN K. Timing of innovation policies when carbon emissions are restricted: an applied general equilibrium analysis. Resource and Energy Economics, 33 (4), 913, 2011.

5. SUN C., ZHANG F., XU M. Investigation of pollution haven hypothesis for China: an ARDL approach with breakpoint unit root tests. Journal of cleaner production, 161, 153, 2017.

6. YUE S., MUNIR I.U., HYDER S., NASSANI A.A., ABRO M.M.Q., ZAMAN K. Sustainable food production, forest biodiversity and mineral pricing: Interconnected global issues. Resources Policy, 65, 101583, 2020.

7. LEACH A.M., EMERY K.A., GEPHART J., DAVIS K.F., ERISMAN J.W., LEIP A., PACE M.L., D'ODORICO P., CARR J., NOLL L.C., CASTNER E., GALLOWAY J.N. Environmental impact food labels combining carbon, nitrogen, and water footprints. Food Policy, 61, 213, 2016.

8. GALLI A., IHA K., HALLE M., EL BILALI H., GRUNEWALD N., EATON D., CAPONE R., DEBS P., BOTTALICO F. Mediterranean countries' food consumption and sourcing patterns: an ecological footprint viewpoint. Science of the Total Environment, 578, 383, 2017.

9. VO X.V., ZAMAN K. Relationship between energy demand, financial development, and carbon emissions in a panel of 101 countries: "go the extra mile" for sustainable development. Environmental science and pollution research international, 27, 23356, 2020.

10. PUI K.L., OTHMAN J. The influence of economic, technical, and social aspects on energy-associated $\mathrm{CO}_{2}$ emissions in Malaysia: An extended Kaya identity approach. Energy, 181, 468, 2019.

11. CEBULlA F., JACOBSON M.Z. Carbon emissions and costs associated with subsidizing New York nuclear instead of replacing it with renewables. Journal of cleaner production, 205, 884, 2018.

12. WORLD BANK. World Development Indicators, World Bank, Washington D.C, 2019. 
13. SHAHBAZ M., HAOUAS I., SOHAG K., OZTURK I. The financial development-environmental degradation nexus in the United Arab Emirates: the importance of growth, globalization and structural breaks. Environmental Science and Pollution Research, 27, 10685, 2020.

14. NIZAM H.A., ZAMAN K., KHAN K.B., BATOOL R., KHURSHID M.A., SHOUKRY A.M., SHARKAWY M.A., ALDEEK F., KHADER J., GANI S. Achieving environmental sustainability through information technology: "Digital Pakistan" initiative for green development. Environmental Science and Pollution Research, 27, 10011, 2020.

15. ANSER M.K., YOUSAF Z., HISHAN S.S., NASSANI A.A., SHEIKH A.Z., VO X.V., ZAMAN K., ABRO M. M. Q. Dynamic linkages between transportation, waste management, and carbon pricing: Evidence from the Arab World. Journal of Cleaner Production, 269, 122151, 2020.

16. DOGAN E., TASPINAR N., GOKMENOGLU K.K. Determinants of ecological footprint in MINT countries. Energy \& Environment, 30 (6), 1065, 2019.

17. SARKODIE S.A., OZTURK I. Investigating the environmental Kuznets curve hypothesis in Kenya: a multivariate analysis. Renewable and Sustainable Energy Reviews, 117, 109481, 2020.

18. WANG X., ZHANG C., ZHANG Z. Pollution haven or porter? The impact of environmental regulation on location choices of pollution-intensive firms in China. Journal of environmental management, 248, 109248, 2019.

19. NASSANI A.A., AWAN U., ZAMAN K., HYDER S., ALDAKHIL A.M., ABRO M.M.Q. Management of natural resources and material pricing: Global evidence. Resources Policy, 64, 101500, 2019.

20. ZHANG G., DENG N., MOU H., ZHANG Z.G., CHEN $\mathrm{X}$. The impact of the policy and behavior of public participation on environmental governance performance: Empirical analysis based on provincial panel data in China. Energy policy, 129, 1347, 2019.

21. WEN H., LEE C.C. Impact of environmental labeling certification on firm performance: Empirical evidence from China. Journal of Cleaner Production, 255, 120201, 2020.

22. SONG M., FISHER R., KWOH Y. Technological challenges of green innovation and sustainable resource management with large scale data. Technological Forecasting and Social Change, 144, 361, 2019.

23. AKRAM R., FAHAD S., HASHMI M.Z., WAHID A., ADNAN M., MUBEEN M., KHAN N., REHMANI M.I.A., AWAIS M., ABBAS M., SHAHZAD K., AHMAD S., HAMMAD H.M., NASIM W. Trends of electronic waste pollution and its impact on the global environment and ecosystem. Environmental Science and Pollution Research, 26, 16923, 2019.
24. MURSHED M. Are Trade Liberalization policies aligned with Renewable Energy Transition in low and middle income countries? An Instrumental Variable approach. Renewable Energy, 151, 1110, 2020.

25. LOSTE N., CHINARRO D., ROLDÁN E., GINER B. Assessing awareness of Green Chemistry as a tool for advancing sustainability. Journal of Cleaner Production, 256, 120392, 2020.

26. CHEN Y., WANG Z., ZHONG Z. $\mathrm{CO}_{2}$ emissions, economic growth, renewable and non-renewable energy production and foreign trade in China. Renewable energy, 131, 208, 2019.

27. REEVES W.R., MCGUIRE M.K., STOKES M., VICINI J.L. Assessing the safety of pesticides in food: How current regulations protect human health. Advances in Nutrition, 10 (1), 80, 2019.

28. MORACANIN S.V., MEMISI N., DJUKIC D., MILIJASEVIC M., BOROVIC B., RASETA M. Air quality and impact on food safety. In IOP Conference Series: Earth and Environmental Science 333 (1), 012111. IOP Publishing, 2019.

29. ZHAO N., LI B., CHEN D., AHMAD R., ZHU Y., LI G., YU Z., LI J., WANG E., YUN S., YOON H., YOON I., ZHOU Y., DONG R., WANG H., CAO J., HE J., JU $\mathrm{X}$. Direct combustion of waste oil in domestic stove by an internal heat re-circulation atomization technology: Emission and performance analysis. Waste Management, 104, 20, 2020.

30. LEE F.L. Internet, citizen self-mobilisation, and social movement organisations in environmental collective action campaigns: Two Hong Kong cases. Environmental Politics, 24 (2), 308, 2015.

31. STHIANNOPKAO S., WONG M.H. Handling e-waste in developed and developing countries: Initiatives, practices, and consequences. Science of the Total Environment, 463, 1147, 2013.

32. BARBAROSSA C., DE PELSMACKER P. Positive and negative antecedents of purchasing eco-friendly products: A comparison between green and non-green consumers. Journal of Business Ethics, 134 (2), 229, 2016.

33. MA Y., RONG K., LUO Y., WANG Y., MANGALAGIU D., THORNTON T.F. Value Co-creation for sustainable consumption and production in the sharing economy in China. Journal of cleaner production, 208, 1148, 2019.

34. WEBER G., CABRAS I., CALAF-FORN M., PUIGVENTOSA I., D'ALISA G. Promoting Waste Degrowth and Environmental Justice at a Local Level: The Case of Unit-Pricing Schemes in Spain. Ecological economics, 156, 306, 2019.

35. ROWE A. Sustainability-ready evaluation: A call to action. New Directions for Evaluation, 2019 (162), 29, 2019. 
